\title{
REGIONAL CLIMATE CHANGE SCENARIOS FOR GREECE: FUTURE TEMPERATURE AND PRECIPITATION PROJECTIONS FROM ENSEMBLES OF RCMS
}

\author{
C.K. TOLIKA* \\ P. ZANIS \\ C. ANAGNOSTOPOULOU
}

Received: $15 / 12 / 10$

Accepted: 06/03/12

\author{
Department of Meteorology and Climatology \\ School of Geology, Aristotle University of Thessaloniki \\ GR 54124, Thessaloniki, Greece
}

\section{ABSTRACT}

The potential regional future changes in seasonal (winter and summer) temperature and precipitation are assessed for the greater area of Greece over the $21^{\text {st }}$ century, under A2, A1B and B2 future emission scenarios of IPCC. Totally twenty-two simulations from various regional climate models (RCMs) were assessed; fourteen of them with a spatial grid resolution of $50 \mathrm{~km}$ for the period 2071-2100 under A2 (9 simulations) and B2 (5 simulations) scenarios and eight of them with an even finer resolution of 25km under A1B scenario for both 2021-2050 and 2071-2100 time periods. The future changes in temperature and precipitation were calculated with respect to the control period (1961-1990). All the models estimated warmer and dryer conditions over the study area. The warming is more intense during the summer months, with the changes being larger in the continental than in the marine area of Greece. In terms of precipitation, the simulations of the RCMs estimate a decrease up to $-60 \%$ (A2 scenario). Finally it is shown that the changes in the atmospheric circulation over Europe play a key role in the changes of the future precipitation and temperature characteristics over the domain of study in a consistent way for the different emission scenarios.

KEYWORDS: Greece, regional climate models, emission scenarios, precipitation and temperature future changes.

\section{INTRODUCTION}

According to the latest IPCC report (IPCC,2007), the Mediterranean area is expected to experience a significant change in its climate, which will became warmer and dryer, due to anthropogenic greenhouse forcing, until the end of the $21^{\text {st }}$ century. In his study Giorgi (2006) characterizes the Mediterranean region as one of the "hot spots", pointing out that the future warming will possibly be larger than the global mean accompanied by a considerable decrease of rainfall. And it is without doubt, that this kind of changes would have substantive impacts on local communities, on the environment and ecosystems as they may adversely affect vital economic sectors such as agriculture and tourism.

It is well known that the Mediterranean basin, located in the transitional zone between the tropical and extra tropical climate systems, combines a variety of geographical components which, associated with several synoptic circulation schemes, present a number of local weather patterns. The complex topography, the sharp orography and the lakes and land -sea contrast, result in a gradual intra-regional variation in the climate of the surrounding lands. Areas toward the coast present either maritime climatic characteristics or arid and semi - arid along the north African areas. On the other hand, other areas adjacent to locations with Mediteranean climates such as the plateaus of central Spain, the Alpine region and the mountainous Pindos zone demonstrate typical characteristics of a continental climate. As Lionello et al. (2008) note, one of the characteristics of the Mediterranean region is the presence of strong mesoscale synoptic/circulation features. These features determine large climatic gradients within this area, which otherwise would lead to a more homogeneous climate. 
More specifically, concerning the eastern part of the Mediterranean basin, where the domain of this study is located (the Greek area), Krichak et al., 2007 mention that the main characteristic of the eastern Mediterranean climate is the joint consequence of the air - sea interactions effects of regional topography. Also, predominant winds result air to dry-off during its way along the upwind slopes of the coastal zone. Moreover, the geographic location of the Greek peninsula as well as its orographic features results in a distinctive climate variation from west to east and from north to south (Maheras and Anagnostopoulou, 2003). Also, the two large water masses (the lonian and the Aegean Sea) influencing and interacting with the main continental body of the country, the mountains in the west and east, the valleys along which the air masses are canalized and the large number of islands play an important role in the precipitation regime of the country.

From the above it becomes evident that the use of just general circulation models for the analysis of the future changes in the climate characteristics of such a complex area could not be considered adequate enough due to their coarse resolution. Many researchers demonstrate that the development of either statistical or dynamical downscaling methodologies could give a more thorough insight of the expected future changes in the Mediterranean area (Somot et al., 2006; Kostopoulou et al., 2007; Krichak et al., 2007; Tolika et al., 2007; Giorgi and Lionello, 2008; Herting and Jacobeit, 2008; Tolika et al., 2008; Zanis et al., 2009). It is expected that the higher the resolution is the better should be the skill of the model in capturing more successfully the microclimate characteristics of each of the Mediterranean sub-regions.

Concerning Greece, studies of the resent past employing either statistical or dynamical downscaling techniques showed that the projections of the models demonstrate a decrease of the future precipitation amounts and raindays. On the other hand an increase of the extreme precipitation indices is expected which will be more pronounced during the winter months (Tolika et al., 2007; Tolika et al., 2008). Similarly to the rest of the Mediterranean area, Greece is expected to experience an increase in maximum, minimum and mean temperature, especially during summer (Zanis et al., 2009) as well as in the frequency of occurrence of heat waves will increase until the end of the $21^{\text {st }}$ century (Tolika et al., 2009). Researchers agree that the use of a general circulation model only, cannot provide detailed regional information in the Greek region. Anagnostopoulou et al., 2008 mention in their study that the HadAM3P model could not succeed in capturing the frequencies of circulation types and it underestimates the rainfall totals (Tolika et al., 2006) over the domain of study (Greece).

Thus, the main scope of this study is: a) to assess the future changes of the temperature and precipitation characteristics over the Greek area under different IPCC future emission scenarios (which are linked to different enhanced green house warming conditions) based on state-of-the art regional climate simulations over Europe carried out in the framework of the PRUDENCE project (http://prudence.dmi.dk/) and the ENSEMBLES project (http://ensembles-eu.metoffice.com), and b) to associate these changes with respective changes in large scale circulation over the broader European domain.

\section{STUDY AREA, DATA AND METHODOLOGY}

Greece, the area under study, is located in the south of the Balkan Peninsula and is roughly encompassed in a window of $34^{\circ}$ to $42^{\circ} \mathrm{N}$ and $18^{\circ}$ to $30^{\circ} \mathrm{E}$ (Figure 1). The large mountain chain of Pindos and the mountains in Peloponissos at the west, play a dominant role in the determination of the climate characteristics of the whole area. On the other hand the eastern and southern parts of the country consist of numerous islands and low altitude areas. This complex topography, the land and sea interactions, the Mediterranean sea - surface temperature distribution as well as the rehumidication of the air masses as they cross the Aegean Sea all contribute to distinctive climate variations from west to east and from north to south (Xoplaki, 2002; Maheras and Anagnostopoulou, 2003). The mean annual temperature ranges from $12^{\circ} \mathrm{C}$ to $20^{\circ} \mathrm{C}$ with a gradient from north to south - southeast. In terms of precipitation, the maximum, on an annual scale, is observed in western Greece (about $1100 \mathrm{~mm}$ ) with a secondary maximum in the east Aegean Sea. The minimum is observed in Cyclades (central Aegean Sea) (less than 400mm) (Anagnostopoulou et al., 2008). The spatial distribution of winter precipitation is quite similar to the annual one and is the season with the largest rainfall amounts reaching $\sim 46 \%$ of the annual totals (Tolika et al., 2006). It is also worth mentioning that one of the climate characteristics of Greece are the very low precipitation totals during the summer months mainly in the southern, coastal and sea areas. On the other hand, some 
times, remarkable amounts of rainfall are recoded in the northern continental and mountainous areas during this season (Lolis et al., 1999; Hatzianastasiou et al., 2008).

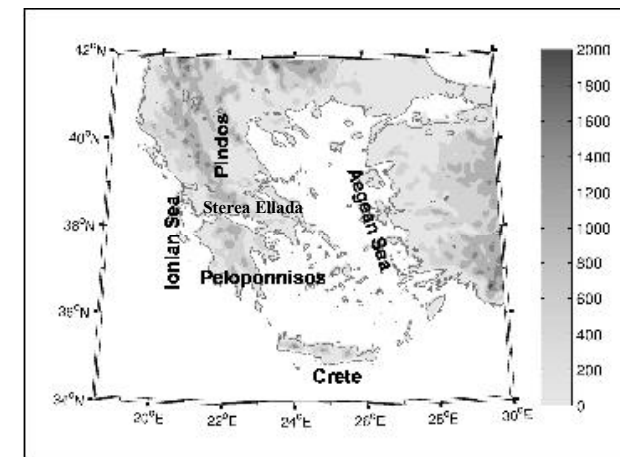

Figure 1. The domain of study. Grey scale represents the altitude in each area (m)

In order to achieve a detail assessment of the future temperature and precipitation conditions over the domain of study, data derived from 17 regional climate models (RCMs hereafter) and 22 individual RCM simulations were utilized. In particular, regional climate projections from 9 RCMs produced within the frame of the PRUDENCE project and from 8 RCMs developed during the ENSEMBLES project. All nine RCMs of PRUDENCE cover Europe with a $50 \times 50 \mathrm{~km}$ resolution and have been forced with 6 hourly lateral boundary conditions provided from the same global model HadAM3H of the Hadley Center (Buonomo et al., 2007) and run for both a control period (19601990) and a far future period (2071-2100) under the A2 SRES (Special Report on Emissions Scenarios) scenario from IPCC, while 5 RCMs run additionally for the future period under the B2 SRES scenario. The $8 \mathrm{RCMs}$ of ENSEMBLES have a finer scale of $25 \mathrm{~km}$ and their projections were forced by the A1B SRES scenario, but their simulations are driven by two different General Circulation Models (GCMs hereafter); 5 RCMs were forced by the same realisation of the ECHAM5 global circulation model while 3 RCMs were forced by HadCM3 global circulation model (2 RCM simulations forced by the normal sensitivity run of HadCM3-Q0 and $1 \mathrm{RCM}$ forced by the high sensitivity run of HadCM3-Q16). For this set of models the data were available for the whole time period starting from 1951 up to 2100 . Table 1 shows baseline information for the RCMs and their simulations that were used in the study as well as their main references.

The A2 scenario is among the worse IPCC future emission scenarios characterized by an independently operating world with continuously increasing population, regionally oriented economic development and slower and more fragmented technological changes and improvements to per capita income. The A1 storyline and scenario family describes a future world of very rapid economic growth, global population that peaks in mid-century and declines thereafter, and the rapid introduction of new and more efficient technologies. Scenario A1B is based on the assumption that similar improvement rates apply to all energy supply and end use technologies. The A2 and A1B are characterized as pessimistic scenarios in which the $\mathrm{CO}_{2}$ concentration will increase up to $815 \mathrm{ppm}$ until the end of the century and on global scale temperature will rise from $2.5^{\circ} \mathrm{C}$ to $4.5^{\circ} \mathrm{C}$.

On the other hand the B2 scenario, a more optimistic one, is more environmentally base with a smaller mean planetary temperature rise ranging from $1.5^{\circ} \mathrm{C}$ to $3.0^{\circ} \mathrm{C}$. All the scenarios families are described in detail by Nakicenovic et al. (2000).

Based on the resolution and the emission scenarios, three groups of models were made in the present study. The meteorological parameters that have been assessed for their future changes are near surface air temperature, precipitation and sea level pressure. They were grouped in three different sets depending on the emission scenario. The first consists of the 9 PRUDENCE models forced by the A2 scenario, the second of the 5 PRUDENCE models with the B2 scenario and the last of the 8 ENSEMBLES models using the A1B scenario. In the case of the PRUDENCE RCMs the seasonal meteorological fields downloaded from the PRUDENCE database (http://prudence.dmi.dk/) were at the same grid point for all RCM simulations and hence the average fields of future changes were directly calculated for the A2 and B2 groups. 
Table 1. The Regional Climate Models used in the study (Acronyms, Institute of origin, Spatial resolution, Emission scenarios, Main references).

\begin{tabular}{|c|c|c|c|c|c|c|}
\hline & $\begin{array}{l}\text { Model } \\
\text { Acronym }\end{array}$ & Institute & Driving GCM & Scenario & Resolution & Main References \\
\hline \multirow{9}{*}{ 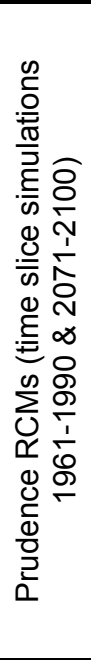 } & CHRM & $\begin{array}{l}\text { ETHZ (Swiss Federal Institute of Technology, Zurich, } \\
\text { Switzerland) }\end{array}$ & HadAM3H & A2 & $50 \mathrm{~km}$ & Vidale et al, 2003 \\
\hline & CLM & GKSS (GKSS Research Center, Geesthacht GmbH, Germany) & HadAM3H & A2 & $50 \mathrm{~km}$ & $\begin{array}{l}\text { Steppeler et al., } \\
2003\end{array}$ \\
\hline & HadRM3H & HC (Hadley Centre for Climate Prediction and Research, UK) & HadAM3H & $\mathrm{A} 2$ and $\mathrm{B} 2$ & $50 \mathrm{~km}$ & $\begin{array}{l}\text { Buonomo et al., } \\
2007\end{array}$ \\
\hline & HIRHAM & DMI (Danish Meteorological Institute, Denmark) & HadAM3H & $\mathrm{A} 2$ and $\mathrm{B} 2$ & $50 \mathrm{~km}$ & $\begin{array}{l}\text { Christensen et al., } \\
1998\end{array}$ \\
\hline & PROMES & UCM (Universidad Complutense de Madrid, Spain) & HadAM3H & $\mathrm{A} 2$ and $\mathrm{B} 2$ & $50 \mathrm{~km}$ & Castro et al., 1993 \\
\hline & RACMO & $\begin{array}{l}\text { KNMI (Royal Netherlands Meteorological Institute, the } \\
\text { Netherlands) }\end{array}$ & HadAM3H & A2 & $50 \mathrm{~km}$ & $\begin{array}{l}\text { Lenderink et al., } \\
2003\end{array}$ \\
\hline & RCAO & $\begin{array}{l}\text { SMHI (Swedish Meteorological and Hydrological Institute, } \\
\text { Sweden) }\end{array}$ & HadAM3H & $\mathrm{A} 2$ and $\mathrm{B} 2$ & $50 \mathrm{~km}$ & $\begin{array}{l}\text { Döscher et al., } \\
2002\end{array}$ \\
\hline & RegCM2 & $\begin{array}{l}\text { ICTP (The Abdus Salam International Centre for Theoretical } \\
\text { Physics, Italy) }\end{array}$ & HadAM3H & $\mathrm{A} 2$ and $\mathrm{B} 2$ & $50 \mathrm{~km}$ & $\begin{array}{l}\text { Giorgi and Mearns } \\
1999\end{array}$ \\
\hline & REMO & MPI (Max-Planck-Institute for Meteorology, Germany) & HadAM3H & A2 & $50 \mathrm{~km}$ & Jacob, 2001 \\
\hline \multirow{8}{*}{ 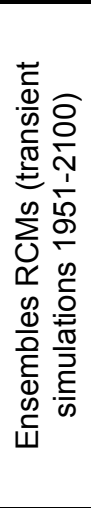 } & CLM & $\begin{array}{l}\text { ETHZ (Swiss Federal Institute of Technology, Zurich, } \\
\text { Switzerland) }\end{array}$ & HadCM3-Q0 & A1B & $25 \mathrm{~km}$ & Böhm et al., 2006 \\
\hline & HadRM3 & HC (Hadley Centre for Climate Prediction and Research, UK) & HadCM3-Q0 & A1B & $25 \mathrm{~km}$ & Collins et al., 2006 \\
\hline & HIRHAM & DMI (Danish Meteorological Institute, Denmark) & ECHAM5-r3 & A1B & $25 \mathrm{~km}$ & Haugen et al., 2006 \\
\hline & RACMO2 & $\begin{array}{l}\text { KNMI (Royal Netherlands Meteorological Institute, the } \\
\text { Netherlands) }\end{array}$ & ECHAM5-r3 & A1B & $25 \mathrm{~km}$ & $\begin{array}{l}\text { Lenderink et al., } \\
2003\end{array}$ \\
\hline & RCA & $\begin{array}{l}\text { SMHI (Swedish Meteorological and Hydrological Institute, } \\
\text { Sweden) }\end{array}$ & ECHAM5-r3 & A1B & $25 \mathrm{~km}$ & $\begin{array}{l}\text { Kjellström et al., } \\
2005\end{array}$ \\
\hline & RCA3 & C41 (Community Climate Change Consortium of Ireland) & HadCM3-Q16 & A1B & $25 \mathrm{~km}$ & Jones et al., 2004 \\
\hline & RegCM3 & $\begin{array}{l}\text { ICTP (The Abdus Salam International Centre for Theoretical } \\
\text { Physics, Italy) }\end{array}$ & ECHAM5-r3 & A1B & $25 \mathrm{~km}$ & Jacob et al., 2007 \\
\hline & REMO & MPI (Max-Planck-Institute for Meteorology, Germany) & ECHAM5-r3 & A1B & $25 \mathrm{~km}$ & Jacob, 2001 \\
\hline
\end{tabular}


In the case of the ENSEMBLES RCMs the meteorological fields of the $8 \mathrm{RCM}$ simulations with A1B were initially interpolated with the statistical package R-project (http://www.r-project.org/) in a common domain at the same grid points separated by 0.25 degrees and then average fields of future changes were calculated. The mean projections derived from these groups were computed for the study area, in order to estimate the future temperature and precipitation changes and compare the differences of the assessments resulting either from the differences in the emission scenarios or from the forcing GCM fields for the RCM simulations. The analysis was made on a seasonal basis (winter and summer) and the future changes were calculated with respect to the control period 19611990. For the ENSEMBLES models temperature and precipitation changes were also estimated for another 30-year period in the middle of the century (2021-2050). It should be noted that the seasonal analysis is confined to winter and summer because these two seasons reflect the seasonal range while autumn and spring can be considered as transition seasons.

In the last part of the study an attempt was also made to explore the relationship and the contribution of the sea level pressure (SLP) to the temperature and precipitation changes in Greece. For that reason, the average atmospheric pressure patterns, obtained from the three groups of models, were created for the reference and the two future periods. Afterwards, the composite maps illustrating the differences (future - control) were analysed in comparison to the equivalent results from the two meteorological parameters under investigation.

Finally, it should be noted that the evaluation of the models was left out of the study since that was part of the research of previous resent studies (Jacob et al., 2007, Maheras et al., 2008, SanchezGomez et al., 2009, Zanis et al., 2009, Rauscher et al., 2010). In general, the PRUDENCE RCMs seem to overestimate winter temperature and precipitation over the Greek area with respect to observational gridded data, while for summer the RCMs showed a variant behaviour over the continental part of Greece and a general cold bias over the marine part (Zanis et al., 2009).

\section{RESULTS}

\subsection{Individual model projections}

Before combining the RCMs in ensembles we wanted to perform a general analysis of each model separately. Table 2 gives the individual model's climate signal, both for temperature and precipitation, as an average of all the grid points covering the Greek area. Overall, the models simulate warmer winters and summers until the end of the $21^{\text {st }}$ century. Concerning the future winter period, it can be seen that the models estimate temperature varying from $9.9^{\circ} \mathrm{C}$ (CLM) to $13.2^{\circ} \mathrm{C}$ (REMO) for the A2 emission scenario, from $9.5^{\circ} \mathrm{C}$ (RegCM2) to $11.3^{\circ} \mathrm{C}$ (RCAO) for $\mathrm{B} 2$ and from $10.8^{\circ} \mathrm{C}$ (RegCM3) to $14.4^{\circ} \mathrm{C}$ (HIRHAM) for the A1B scenario for the period 2071-2100.

It is worth noticing that the models presenting the greatest future winter temperatures are not also the ones having the greatest future change with respect to the reference period 1961-1990. For example the RCMs estimate winter temperature changes for the period 2071-2100 varying from $3.1^{\circ} \mathrm{C}$ (CHRM) to $3.8^{\circ} \mathrm{C}$ (HIRHAM) for A2, from $2.4{ }^{\circ} \mathrm{C}$ (RegCM2 and RCAO) to $2.7^{\circ} \mathrm{C}$ (PROMES) for $\mathrm{B} 2$ and from $2.9^{\circ} \mathrm{C}$ (RCA) to $4^{\circ} \mathrm{C}$ (RCA3) for the A1B scenario. It should be noted that the highest temperature change estimated with RCA3 is to great extent determined by the high sensitivity run of the driving GCM (HadCM3-Q16). So according to the normal sensitivity run of the driving GCM (HadCM3-Q0) the projected winter temperature change for the greater area of Greece is $3.4{ }^{\circ} \mathrm{C}$ while for the high sensitivity run (HadCM3-Q16) is $4.2^{\circ} \mathrm{C}$. On the other hand, for summer it is clear that HadRM3P, from PRUDENCE models, is the warmest and one presenting the most intense climate signal for both $\mathrm{A} 2$ and $\mathrm{B} 2$ emission scenarios. The model average projections over the study area show that temperature will reach at maximum $29.5{ }^{\circ} \mathrm{C}\left(5.4{ }^{\circ} \mathrm{C}\right.$ increase from the control run period) for $\mathrm{A} 2$ and $28.3^{\circ} \mathrm{C}\left(4.2^{\circ} \mathrm{C}\right.$ increase $)$ for $\mathrm{B} 2$. 
Table 2. Average temperature and precipitation projections for individual models.

\begin{tabular}{|c|c|c|c|c|c|c|c|c|c|c|c|c|c|c|c|c|c|}
\hline & \multicolumn{4}{|c|}{ winter } & \multicolumn{4}{|c|}{ summer } & \multicolumn{4}{|c|}{ winter } & \multicolumn{4}{|c|}{ summer } \\
\hline & & \multicolumn{2}{|c|}{ A2 } & \multicolumn{2}{|c|}{ B2 } & \multicolumn{2}{|c|}{ A2 } & \multicolumn{2}{|c|}{ B2 } & \multirow{2}{*}{\multicolumn{2}{|c|}{$\frac{\text { A2 }}{2071-2100}$}} & \multirow{2}{*}{\multicolumn{2}{|c|}{$\frac{\text { B2 }}{2071-2100}$}} & \multirow{2}{*}{\multicolumn{2}{|c|}{$\begin{array}{c}\text { A2 } \\
2071-2100\end{array}$}} & \multirow{2}{*}{\multicolumn{2}{|c|}{$\frac{\text { B2 }}{2071-2100}$}} \\
\hline & & \multicolumn{2}{|c|}{$2071-2100$} & \multicolumn{2}{|c|}{$2071-2100$} & \multicolumn{2}{|c|}{$2071-2100$} & \multicolumn{2}{|c|}{$2071-2100$} & & & & & & & & \\
\hline & & T2m & dT2m & T2m & dT2m & T2m & dT2m & T2m & dT2m & Mean Prec & dPrec(\%) & Mean Prec & dPrec $(\%)$ & Mean Prec & dPrec(\%) & Mean Prec & dPrec(\%) \\
\hline \multirow{12}{*}{$\begin{array}{l}\sum_{0}^{\infty} \\
0 \\
\alpha \\
0 \\
0 \\
\frac{1}{0} \\
0 \\
0 \\
2 \\
0\end{array}$} & CHRM & 10.6 & 3.1 & & & 27.2 & 4.4 & & & 152.4 & -13.1 & & & 10.9 & -71.0 & & \\
\hline & CLM & 9.9 & 3.4 & & & 25.9 & 4.0 & & & 150.2 & -12.1 & & & 8.1 & -72.9 & & \\
\hline & HadRM 3P & 12.2 & 3.6 & 11.1 & 2.5 & 29.5 & 5.4 & 28.3 & 4.2 & 167.3 & -20.7 & 167.3 & -20.7 & 23.3 & -57.0 & 32.8 & -39.6 \\
\hline & HIRHAM & 12.3 & 3.8 & 11.0 & 2.5 & 28.3 & 4.7 & 26.9 & 3.3 & 181.9 & -6.9 & 215.8 & 10.5 & 44.1 & -37.0 & 57.5 & -17.7 \\
\hline & PROMES & 11.5 & 3.5 & 10.8 & 2.7 & 27.7 & 5.0 & 26.7 & 4.0 & 194.7 & -6.9 & 215.3 & 2.9 & 31.2 & -49.5 & 37.2 & -39.7 \\
\hline & RACMO & 111.8 & 3.7 & & & 29.1 & 5.2 & & & 135.9 & -9.8 & & & 8.1 & -63.8 & & \\
\hline & RCAO & 12.5 & 3.6 & 11.3 & 2.4 & 29.4 & 4.9 & 27.9 & 3.5 & 146.2 & -9.1 & 180.5 & 12.2 & 10.8 & -58.7 & 19.4 & -26.0 \\
\hline & RegCM2 & 10.9 & 3.7 & 9.5 & 2.4 & 28.1 & 4.7 & 26.6 & 3.1 & 204.0 & -11.5 & 240.1 & 4.1 & 34.4 & -39.0 & 47.1 & -16.5 \\
\hline & REMO & 13.2 & 3.7 & & & 28.3 & 4.4 & & & 205.1 & \begin{tabular}{|c|}
-11.4 \\
\end{tabular} & & & 55.0 & -28.0 & & \\
\hline & Mean & 11.7 & 3.6 & 10.7 & 2.5 & 28.2 & 4.8 & 27.2 & 3.6 & 170.9 & -11.3 & 203.8 & 1.8 & 25.1 & -53.0 & 38.8 & -27.9 \\
\hline & Min & 9.9 & 3.1 & 9.5 & 2.4 & 25.9 & 4.0 & 26.6 & 3.1 & 135.9 & -20.7 & 167.3 & -20.7 & 8.1 & -72.9 & 19.4 & -39.7 \\
\hline & Max & 13.2 & 3.8 & 11.3 & 2.7 & 29.5 & 5.4 & 28.3 & 4.2 & 205.1 & -6.9 & 240.1 & 12.2 & 55.0 & -28.0 & 57.5 & -16.5 \\
\hline
\end{tabular}

\begin{tabular}{|c|c|c|c|c|c|c|c|c|c|c|c|c|c|c|c|c|c|}
\hline \multirow[b]{4}{*}{ V } & & \multirow{2}{*}{\multicolumn{4}{|c|}{$\begin{array}{c}\text { winter } \\
\text { A1B }\end{array}$}} & \multirow{2}{*}{\multicolumn{4}{|c|}{$\frac{\text { summer }}{\text { A1B }}$}} & \multirow{2}{*}{\multicolumn{4}{|c|}{$\frac{\text { winter }}{\text { A1B }}$}} & \multirow{2}{*}{\multicolumn{4}{|c|}{$\frac{\text { summer }}{\text { A1B }}$}} \\
\hline & & & & & & & & & & & & & & & & & \\
\hline & & \multicolumn{2}{|c|}{$\begin{array}{r}\text { A } \\
2021-2050\end{array}$} & \multicolumn{2}{|c|}{$2071-2100$} & \multicolumn{2}{|c|}{$2021-2050$} & \multicolumn{2}{|c|}{$2071-2100$} & \multicolumn{2}{|c|}{$2021-2050$} & \multicolumn{2}{|c|}{$2071-2100$} & \multicolumn{2}{|c|}{$2021-2050$} & \multicolumn{2}{|c|}{$2071-2100$} \\
\hline & & $T 2 m$ & dT2m & T2m & dT2m & T2m & dT2m & T2m & dT2m & Mean Prec & dPrec(\%) & Mean Prec & dPrec(\%) & Mean Prec & dPrec(\%) & Mean Prec & dPrec(\%) \\
\hline \multirow{11}{*}{ 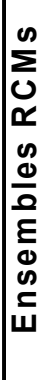 } & CLLM & 10.5 & 1.5 & 12.3 & 3.3 & 25.5 & 2.2 & 27.4 & 4.1 & 288.2 & $\begin{array}{l}-6.9 \\
\end{array}$ & 285.8 & -7.7 & 15.0 & -26.7 & 10.4 & -49.5 \\
\hline & HadRM 3 & 11.5 & 1.7 & 13.3 & 3.4 & 26.5 & 2.5 & 28.8 & 4.8 & 241.8 & -9.3 & 230.7 & $\begin{array}{l}-13.4 \\
\end{array}$ & 32.8 & -10.1 & 24.7 & -32.1 \\
\hline & HIRHAM & 12.5 & 1.1 & 14.4 & 2.9 & 25.0 & 1.5 & 27.2 & 3.7 & 307.2 & -2.3 & 251.8 & -19.9 & 18.7 & -20.0 & 14.2 & -39.3 \\
\hline & RACMO2 & 10.7 & 1.2 & 12.6 & 3.1 & 24.4 & 1.6 & 26.7 & 3.8 & 197.4 & -3.9 & 171.4 & -16.6 & 8.1 & -34.3 & 6.7 & -45.2 \\
\hline & RCA & 10.7 & 1.1 & 12.5 & 2.9 & 23.1 & 1.5 & 25.2 & 3.7 & 197.8 & 2.0 & 174.2 & -10.2 & 18.7 & -25.4 & 14.5 & -41.9 \\
\hline & RCA3 & 10.8 & 2.0 & 12.8 & 4.0 & 27.8 & 2.8 & 30.9 & 5.9 & 164.1 & -10.5 & 138.0 & -24.7 & 19.7 & -17.5 & 16.9 & -29.3 \\
\hline & RegCM 3 & 8.9 & 1.2 & 10.8 & 3.0 & 23.2 & 1.5 & 25.8 & 4.1 & 227.9 & 2.1 & 191.3 & -14.3 & 37.2 & 2.4 & 30.0 & -17.5 \\
\hline & REMO & 11.7 & 1.2 & 13.6 & 3.1 & 24.4 & 1.7 & 26.7 & 3.9 & 217.3 & -1.3 & 188.4 & -14.4 & 23.6 & -20.7 & 17.8 & -40.3 \\
\hline & Mean & 10.9 & $\overline{1.4}$ & 12.8 & 3.2 & 25.0 & 1.9 & 27.3 & 4.3 & 230.2 & -3.7 & 203.9 & -15.1 & 21.7 & -19.0 & 16.9 & -36.9 \\
\hline & M in & 8.9 & 1.1 & 10.8 & 2.9 & 23.1 & 1.5 & 25.2 & 3.7 & 164.1 & -10.5 & 138.0 & -24.7 & 8.1 & -34.3 & 6.7 & -49.5 \\
\hline & Max & 12.5 & 2.0 & 14.4 & 4.0 & 27.8 & 2.8 & 30.9 & 5.9 & 307.2 & 2.1 & 285.8 & -7.7 & 37.2 & 2.4 & 30.0 & -17.5 \\
\hline
\end{tabular}


Analogous were the results for the RCA3 model (from the ENSEMBLES group) characterized by the largest summer temperature increase as well as the highest actual temperature magnitudes, which for the second future period are even larger than the ones from the other two emission scenarios reaching $30.9^{\circ} \mathrm{C}\left(5.9^{\circ} \mathrm{C}\right.$ increase from the control run period). The RCA3 estimates in summer are again to great extent determined by the high sensitivity run of the driving GCM (HadCM3-Q16). For example, the projected winter temperature change for the greater area of Greece from HadCM3-Q0 is $4.9^{\circ} \mathrm{C}$ while from HadCM3-Q16 is $6.1^{\circ} \mathrm{C}$.

In terms of precipitation all models forced by the $\mathrm{A} 2$ and $\mathrm{A} 1 \mathrm{~B}$ scenarios indicate generally dryer winter conditions by the end of the $21^{\text {st }}$ century. The average percentage of change ranges from $6.9 \%$ (HIRHAM and PROMES) up to $-20.7 \%$ (HadRM3P) for the former scenario and from $-7.7 \%$ (CLM) to $-24.7 \%$ (RCA3) for the latter. The mid - century projections of the A1B ENMSEBLES models showed a much lower precipitation decrease and two of the models (RCA and RegCM3) estimated a slight increase of the average rainfall heights $(2.0 \%$ and $2.1 \%$ respectively). In the case of the B2 scenario, four out of the five models project an average precipitation increase over Greece reaching $12.2 \%$ for RCAO model. Finally, a more intense drying is predicted by all the models for the summer months. The percentages of decrease range from $-16.5 \%$ (RegCM2, B2 scenario) up to $72.9 \%$ (CLM, A2 scenario) with the rest of the models presenting a decrease that vary between these values. The only exception is RegCM3 which present a small increase of the summer precipitation values but only for the period 2021-2050 (2.4\%, A1B scenario) (Table 2).

Finally, the values of standard deviation for the different groups of RCMs (shown in Table 3 ) provide and indication of the related variance in temperature $(\mathrm{dT} 2 \mathrm{~m})$ and precipitation (dPrec) responses in late century future climate change (2071-2100 with respect to 1961-1990) for winter and summer. The first group (All RCMs) includes all simulations used in this study from both PRUDENCE and ENSEMBLES without limitations concerning the IPCC scenario or the driving GCM. Generally, there is a tension for the variance to be reduced when sub-groups of RCM simulations are set with respect the IPCC scenario or the driving GCM. In case of PRUDENCE, all A2 simulations were carried out under the same driving GCM (HadAM3). Similarly all B2 simulations were carried out under the same driving GCM. However in case of ENSEMBLES, the A1B simulations were forced by different GCMs (ECHAM and HadCM3) which justifies the higher standard deviation of $d T 2 m$ in group A1BENSEMBLES compared to groups A2-PRUDENCE and B2-PRUDENCE for both winter and summer. Furthermore Table 3 shows that the variance of $d T 2 m$ in group A1B-ENSEMBLES is reduced significantly when we further group the A1B simulations with respect the forcing GCM. As far as it concerns the variance in precipitation change from Table 3 the results with respect the IPCC scenario or the driving GCM are to a certain extend in line with those for temperature but with exceptions. For example mind that the variance of precipitation change in winter for B2 is the highest as there are some RCMs showing decrease in late $21^{\text {st }}$ century precipitation and others an increase.

Table 3. Standard deviation of temperature $(\mathrm{dT} 2 \mathrm{~m})$ and precipitation (dPrec) projections at the end of $21^{\text {st }}$ century (2071-2100 with respect to 1961-1990) for different groups of RCMs

\begin{tabular}{|l|c|c|c|c|}
\hline & \multicolumn{2}{|c|}{ Winter } & \multicolumn{2}{c|}{ Summer } \\
\hline All RCMs & $\mathrm{dT2m}(\mathrm{K})$ & $\mathrm{dPrec}(\%)$ & $\mathrm{dT2m}(\mathrm{K})$ & $\mathrm{dPrec}(\%)$ \\
\hline & 0.49 & 9.65 & 0.71 & 16.18 \\
\hline A2 - PRUDENCE & 0.21 & 4.15 & 0.46 & 15.71 \\
\hline B2 - PRUDENCE & 0.13 & 13.20 & 0.49 & 11.33 \\
\hline A1B - ENSEMBLES & 0.34 & 5.35 & 0.74 & 10.19 \\
\hline ECHAM - ENSEMBLES & 0.07 & 3.55 & 0.17 & 11.04 \\
\hline HadCM3 - ENSEMBLES & 0.11 & 4.03 & 0.48 & 12.30 \\
\hline
\end{tabular}

\subsection{Future temperature projections}

All the RCM models used agree that for both the future periods (2021-2051 and 2071-2100) there will be an increase of the winter temperature, with respect to the 1961-1990 reference period. As it was expected, the magnitude of the positive differences found is increasing with increasing greenhouse gas forcing. It can be seen that the temperature rise will be larger over the central and northern continental parts of the country. More specifically, the PRUDENCE models, driven by the 
A2 emission scenario, estimate that the north Greece will experience the most significant warming during winter, with temperatures rising up to $4.5^{\circ} \mathrm{C}$ (Figures $2 \mathrm{a}$ and $2 \mathrm{~b}$ ). For the rest of the study area the temperature increase will be 0.5 to 1.5 degrees lower. The pattern of change derived from the PRUDENCE B2 models is quite similar, but the magnitude of change is lower (increase about 2.5 to $3.0^{\circ} \mathrm{C}$ over the continent).

The finer spatial resolution of the ENSEMBLES models gave a more detailed picture of the future changes especially over land. For the first future period (the mid-century period 2021-2050) the results are close to end-century PRUDENCE B2 model results, but the temperature increase is 1.5 degree lower (Figure 2c). For the end-century period 2071-2100, the signal of change is more intense and the winter temperatures are expected to increase up to $4.0^{\circ} \mathrm{C}$ with the maximum warming seen again in northern and central continental Greece (Figure 2d).

It is worth noticing that the first two sets of models predict larger positive differences in northern and eastern Aegean Sea $\left(\mathrm{A} 2\left(3.5^{\circ} \mathrm{C}-4.0^{\circ} \mathrm{C}\right)\right.$ and $\left.\mathrm{B} 2\left(2.5^{\circ} \mathrm{C}-3.0^{\circ} \mathrm{C}\right)\right)$ in comparison to the lonian Sea (about $0.5^{\circ} \mathrm{C}$ less). On the other hand, for the first future period, the ENSEMBLES models project the same warming for both seas $\left(1^{\circ} \mathrm{C}-1.5^{\circ} \mathrm{C}\right)$, except for a quite small area at the north of the Aegean Sea where the temperature increase is higher (Figure 2c). For the last 30 years of the 21st century, this set of models showed a quite distinct change between the two seas. The warming of the Aegean Sea is clearly larger than the warming of the Ionian Sea.

In comparison to the rest of the European region (not shown), Greece, is expected to have a quite larger future temperature change than other parts of the continent. However, all the assessments are in agreement of an overall warming of Europe during the winter months. From the composite maps of the differences between the future and the control period, it was found that the smallest temperature increase is expected at the north-western parts and it becomes more pronounced going eastwards. The north-eastern parts of Europe are the ones that will experience the most intense warming. However, the magnitude of change differs from one forcing scenario to the other (Figure 2d).

a) dT2m Winter PRUDENCE A2 (2071-2100)

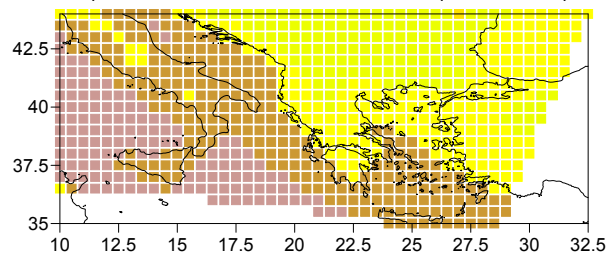

c) dT2m Winter ENSEMBLES A1B (2021-2050)

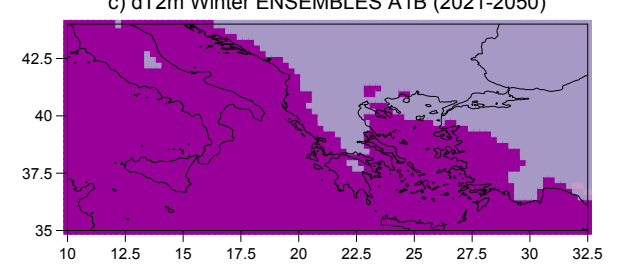

b) dT2m Winter PRUDENCE B2 (2071-2100)

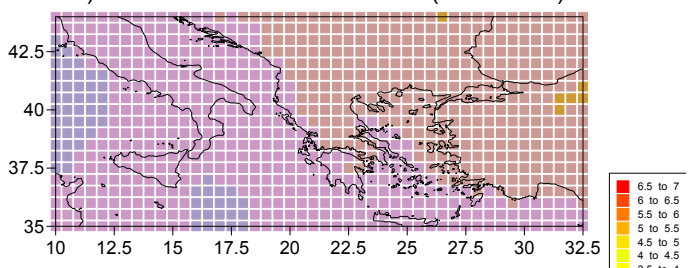

d) dT2m Winter ENSEMBLES A1B (2071-2100)

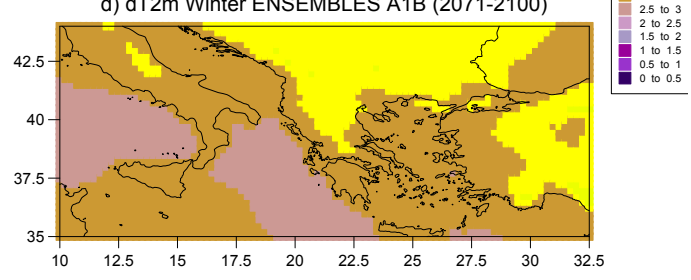

Figure 2. Future change $\left({ }^{\circ} \mathrm{C}\right)$ of winter temperatures over Greece as derived from the three groups of different emission scenarios models (PRUDENCE and ENSEMBLES) for the two future periods (2021-2050 and 2071-2100) with respect to the reference period 1960-1990.

The summer warming is found to be even larger than winter, but the spatial distribution of the differences is quite similar (Figure 3). The strongest temperature rise occurs over the continental parts of the country. The climate change experiments from the PRUDENCE set of models project, according to the $\mathrm{A} 2$ scenario, an increase up to $6^{\circ} \mathrm{C}$ for northern and central Greece. As we move to the coastal areas the temperature rise is lower and in central and southern Aegean Sea the warming is up to $4.5^{\circ} \mathrm{C}$. The corresponding results from the B2 scenario show a less intense temperature increase. Once more, western central and northern Greece will experience the highest summer temperatures $\left(4.0-4.5^{\circ} \mathrm{C}\right)$ while for the rest of the country the warming is $0.5^{\circ} \mathrm{C}$ to $1.0^{\circ} \mathrm{C}$ lower. Estimations of simulation from the ENSEMBLES models showed for the first future period (2021$2050)$ that the warming is quite uniform over the continent $\left(2-2.5^{\circ} \mathrm{C}\right)$ and almost 1 degree less over the maritime parts of Greece. For the last 30 years of the century the climate signal remains of the 
same sign as before (temperature rise), but the warming is much more pronounced. Moving from the costal areas to the central and northern continental Greece the magnitude of change increases reaching the value of $5.5^{\circ} \mathrm{C}$ (half a degree less than the $A 2$ forcing) (Figure $3 \mathrm{c}-\mathrm{d}$ ).
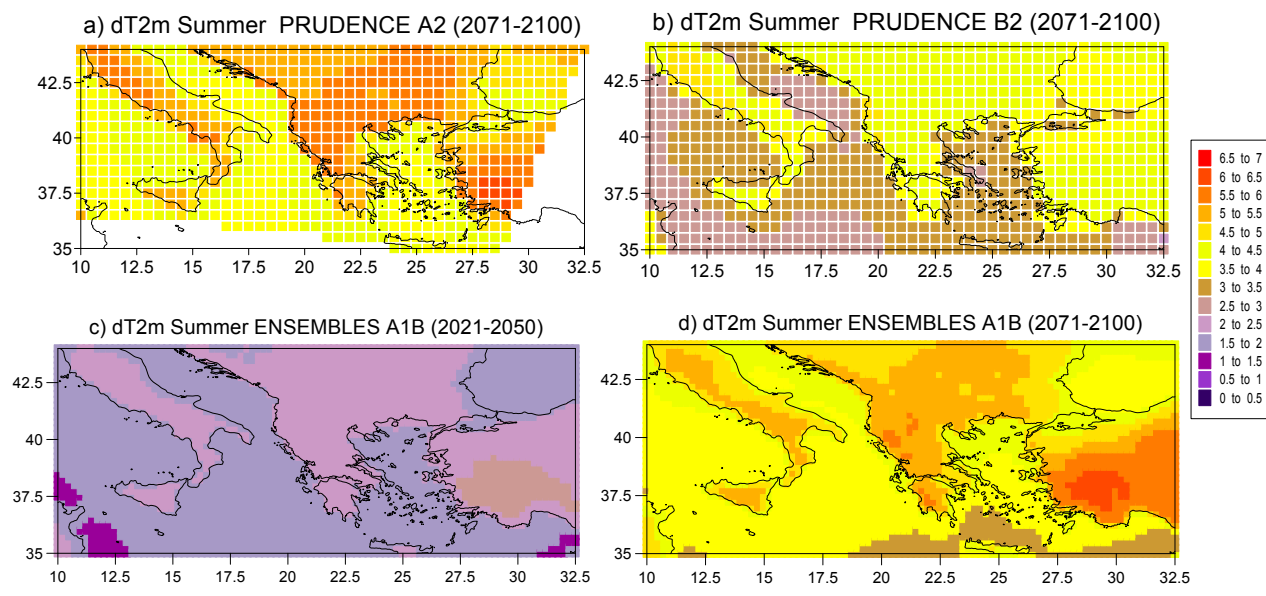

Figure 3. As in Figure 2 but in the case of summer.

From the equivalent results for the whole European area (not shown) it was evident that the future summer temperature increase will be broad and the climate signal is stronger than winter's. Generally, the warming will be greater over central and mainly over southern Europe. Except for Greece, other parts that are expected to have the maximum summer warming are the central Iberian Peninsula, southern France and Italy. According to the A2 forcing scenario the temperature rise will reach the value of $6.5^{\circ} \mathrm{C}$ during the future summer months. Also, all the model groups agree that the British Isles will experience a relatively smaller warming than the rest of the European region.

\subsection{Future precipitation projections}

The results from the $A 2$ and $A 1 B$ (both future periods) forcing scenarios showed that the domain of study would exhibit a general reduction of precipitation during winter (Figure 4). This decrease becomes progressively more intense towards the south. In detail, the first set of PRUDENCE models (Figure 4a) simulates lower rainfall heights (- 5 to $-15 \%)$ at the northern and central parts of the country, as well as in the Ionian Sea, and an even greater decrease in Sterea Ellada, Peloponissos and Crete that reach the value of $-30 \%$, in comparison to the reference time period (1961-1990). Concerning the ENSEMBLES models, a more detail distribution of the estimated differences is evident, probably due to their finer spatial resolution. The precipitation decrease is more pronounced during the last 30 years of the 21st century, mainly over the areas of Peloponissos and southern Aegean Sea (up to $-30 \%$ ) (Figure $4 d$ ).

Conversely it can be noted that the PRUDENCE group of models, forced by the B2 emission scenario, presented quite different estimations (Figure $4 \mathrm{~b}$ ). A rainfall increase up to $10 \%$ is observed over central and northern continental Greece as well as in the largest part of the Aegean Sea. The area of precipitation decrease is limited and the magnitude of change is smaller (up to $-15 \%$ ) than the rest of the models estimations. It can be clearly seen that the transition zone from precipitation decrease to precipitation increase as we move from south to north, is southern for the group of RCMs forced by $\mathrm{B} 2$ than in the groups forced by $\mathrm{A} 2$ or A1B.

In terms of the precipitation projections for the rest of the European region, the results from all the models are generally consistent (not shown). Central and northern Europe is expected to have in the future wetter conditions during winter with the precipitation increase ranging from $5 \%$ to $45 \%$ (for limited areas according to the A2 scenario). On the other hand, for the Mediterranean area, as for Greece, the models suggest that in the future the winter rainfall will be less. The only exception was found for the A1B ENESEMBLES set, for the first future period, where even the lberian Peninsula and Italy will experience a small precipitation increase (up to $10 \%$ ). 

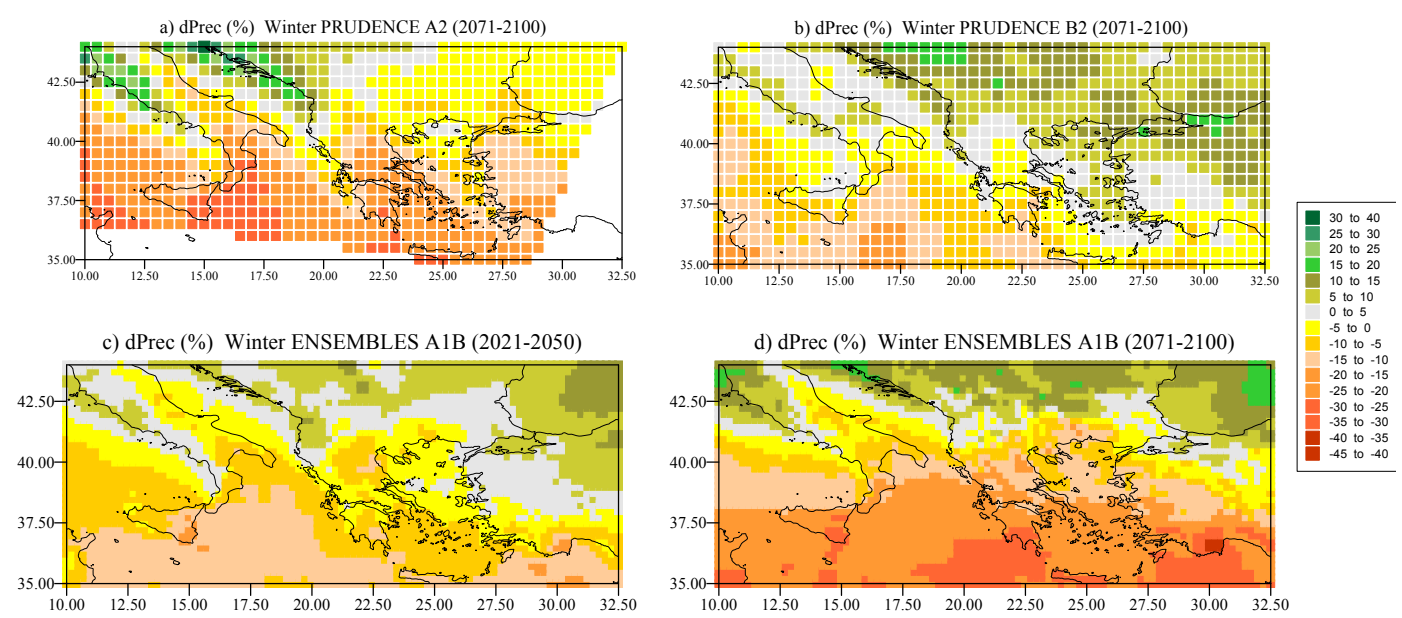

Figure 4. Percentage (\%) of future winter precipitation change over Greece as derived from the three groups of different emission scenarios models (PRUDENCE and ENSEMBLES) for the two future periods (2021-2050 and 2071-2100) with respect to the reference period 1960-1990.

The spatial characteristics of the summer future precipitation changes are shown in Figure 5. Overall, the maps reveal a summer drying all over the study area with higher percentages of change compared to the winter's ones. For the PRUDENCE A1 projections the precipitation decrease exceeds $-60 \%$ in southwestern Greece and in the eastern Aegean Sea. This comes in agreement with the simulations of the ENSEMBLES models for the first future period, since the aforementioned areas are the ones that will experience the greatest rainfall reduction but of smaller magnitude (up to $-30 \%$ ). It is worth mentioning that in some areas the rainfall decrease will double by the end of the 21st century compared to 2021-2050. In the case of B2 forcing scenario, although a precipitation decrease characterizes the largest part of the country, two areas, central Aegean Sea and a small part of Crete, have the opposite climate signal (precipitation increase 10\%). This percentage of change of precipitation in summer has to be considered with caution as practically we have little or even no precipitation especially in Aegean and Crete. So, one single precipitation event may lead to significant precipitation changes in the future. Also, it should be taken under consideration that the B2 scenario is a mild future scenario and it is more humid and less warm than the A2 scenario for the Mediterranean.

The multi-model means for the three SRES scenarios agree that the precipitation reduction will be much more extended in Europe during summer. The drying conditions are expected to characterize the largest part of the continent. The only exceptions are Scandinavia and some parts of the northeastern Europe where the models predict that rainfall will increase in the future from $20 \%(\mathrm{~A} 1 \mathrm{~B})$ to $80 \%(A 2)$.
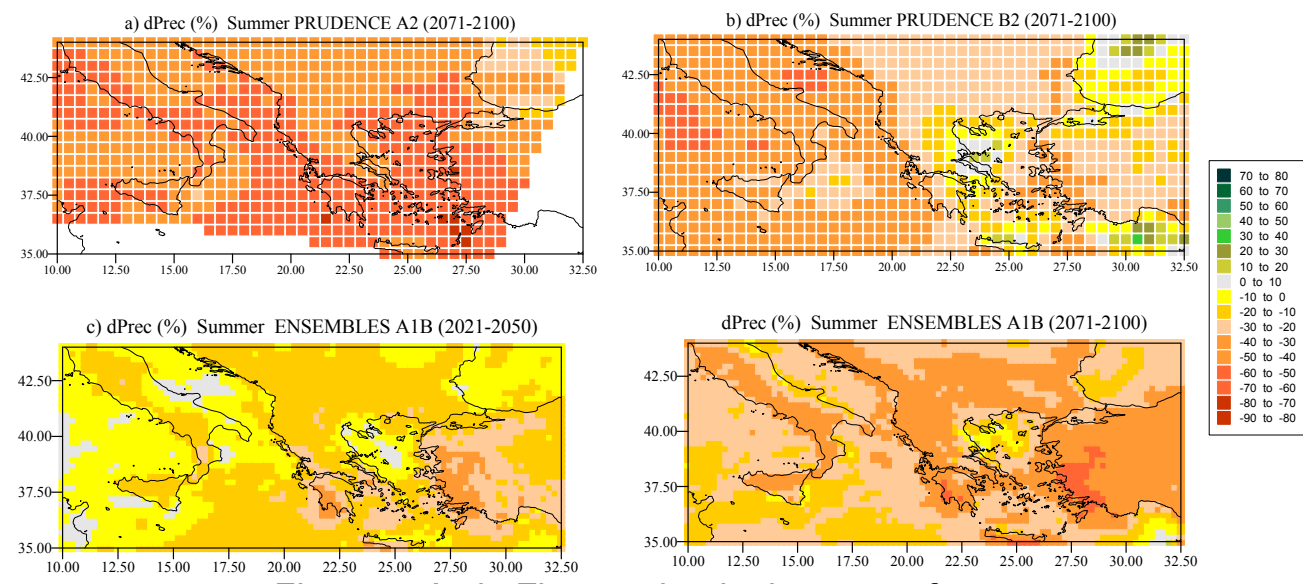

Figure 5. As in Figure 4 but in the case of summer 


\subsection{Future changes in the atmospheric circulation (SLP)}

In association to the latitudinal gradient of the SLP future changes in winter it is a common feature of all the models that in the future there will be a clear prevalence and enhancement of a westerly flow over the northern Europe with a direction SW to NE. Such a feature is strongest for the A2 group where we notice the largest gradients of change and weakest for the mid-century A1B group that the smallest SLP gradients are seen. This zonal circulation (westerly winds) is more pronounced during winter, when the airflow in the northern hemisphere is stronger and the strength of the westerlies is determined by the temperature gradient (Barry and Carleton, 2001). At a further investigation it was found that the winter meridional temperature gradients at SLP level in Europe (between the Mediterranean and the northern part of Europe) were very close for the A2 and B2 emission scenarios (not shown). On the other hand, the weakness of the temperature gradient for the A1B indicates also a quite weaker zonal flow over Europe.

It should be noted that in winter, the PRUDENCE RCMs closely follow the circulation changes simulated by the driving global model HadAM3H with a clear enhancement of the strength of westerly flows (van Ulden et al., 2007) which in turn can be associated with a shift to the north of the sub-tropical jet stream. It should be also noted that HadAM3H in comparison with the reanalysis ERA-40 provides a reasonably good simulation of the mean sea level pressure pattern although it exhibits a stronger pressure gradient across a large part of Central to Northern Europe than the reanalysis which is mainly caused by too high pressure over the Mediterranean region and too deep Icelandic low extending too far into the Nordic seas (Jacob et al., 2007). A common feature of the IPCC GCMs is to predict a strengthening and a poleward shift of the tropospheric zonal jets in response to global warming (Lorenz and DeWeaver, 2007).

Moreover, it is worth mentioning that although the PRUDENCE models predict a small decrease of the SLP, still the future mean sea level actual values are much higher over Greece in comparison to the ENSEMBLES models (1020hPa for PRUDENCE and 1016-1018hPa for the ENSEMBLES). A result that was not quite expected was the more intense future SLP change from the B2 scenario in comparison to A1B which is considered as less optimistic than the B2. This could probably be attributed to the different driving GCMs that are used in these two sets of models and not to the forcing scenarios.

In the case of summer (Figure 7 a-d) the future SLP changes according to the A2 and B2 scenarios show a reverse bipolar structure with a future increase in northwestern Europe (up to $2.5 \mathrm{hPa}$ ) and a decrease at the south - southeastern parts (up to $3 \mathrm{hPa})$. The NW $(0 \mathrm{E}, 60 \mathrm{~N})$ to SE $(25 \mathrm{E}, 35 \mathrm{~N})$ gradient of summer SLP changes calculated to be $-3.7 \mathrm{hPa}$ for $\mathrm{A} 2$ group (Figure 7a), $-2.7 \mathrm{hPa}$ for the $\mathrm{B} 2$ group (Figure $7 \mathrm{~b}$ ), $-2.0 \mathrm{hPa}$ for the end-century A1B group (Figure $7 \mathrm{~d}$ ) and $-0.7 \mathrm{hPa}$ for the mid-century A1B group (Figure 7c).

a) d MSLP Summer PRUDENCE A2 (2071-2100)

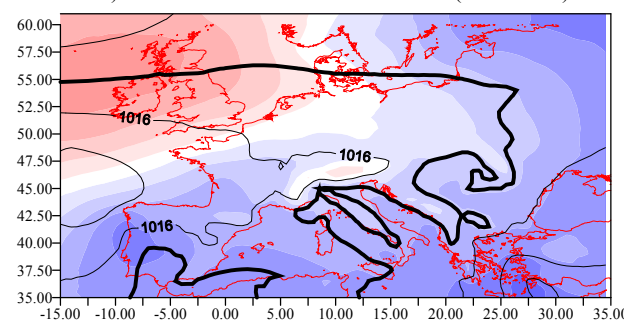

c) d MSLP Summer ENSEMBLES (2021-2050)

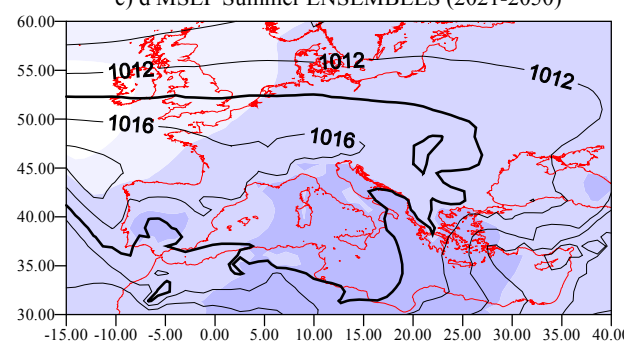

b) d MSLP Summer PRUDENCE B2 (2071-2100)

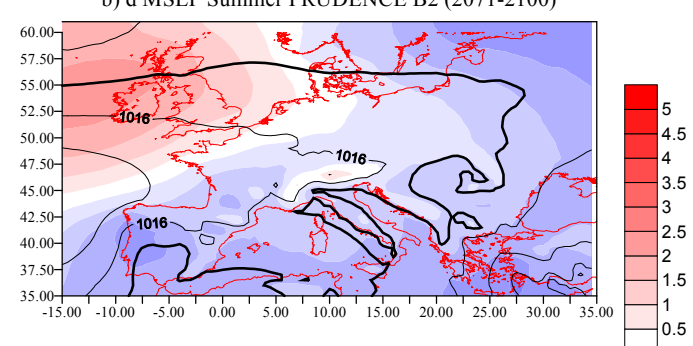

d) d MSLP Summer ENSEMBLES (2071-2100)

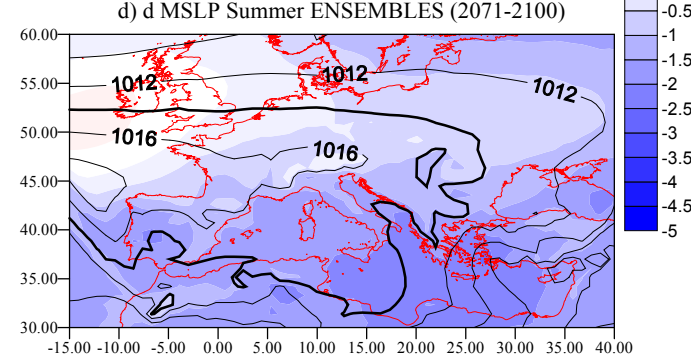

Figure 7. As in Figure 6 but in the case of summer 
In association to the reverse latitudinal gradient of the SLP future changes in summer (with positive SLP anomalies over the British Isles and negative SLP anomalies in Mediterranean) the most prominent circulation response in the RCMs is a weakening of westerly zonal (van Ulden et al., 2007) and possibly more frequent stagnant conditions. Many climate change simulations show that such circulation changes, are associated with an increase in the incidence of warm summers and more frequent heat waves in the future climate (Schär et al., 2004; Meehl and Tebaldi, 2004).

The patterns of change in the circulation as derived from the ENSEMBLES models agree in the predominance of negative differences over the south with the maximum appearing over the Greek area. However, the positive pole hardly exists and the positive differences do not exceed the value of $1 \mathrm{hPa}$ (for the second future period). Conversely to winter, the geographical distribution of the SLP future isobars, which is very similar in all the projections, show that the highest $(1018 \mathrm{hPa})$ (lowest $(1008 \mathrm{hPa})$ ) values are found in western (southeastern) Europe and in general the pressure gradient is much weaker than the winter's one.

\section{CONCLUSIONS AND DISCUSSION}

In the present study we analysed the potential seasonal (winter and summer) future changes in temperature and precipitation conditions over the Greek area as a consequence of the enhanced green house gas concentrations until the end of the $21^{\text {st }}$ century. Totally 22 simulations from 17 regional climate models (RCMs) were assessed. Fourteen of the RCM simulations were developed during the PRUDENCE project (horizontal resolution of $50 \mathrm{~km}$ ) under A2 (9 simulations) and B2 (5 simulations) scenarios and eight of them during the ENSEMBLES project (horizontal resolution of $25 \mathrm{~km}$ ) under A1B scenario. The RCM simulations were grouped into three ensemble - means depending on the different IPCC emission scenarios (A2, B2 and A1B) and the climatic changes over the domain of study were computed for two different future periods (2021-2050 and 2071-2100) with respect to the control period 1961-1990.

The main conclusions drawn from the study are the following:

1. The warming during winter is in range of about 3 to $4.5^{\circ} \mathrm{C}$ for the $\mathrm{A} 2$ run, 3 to $4^{\circ} \mathrm{C}$ for $\mathrm{A} 1 \mathrm{~B}$ and 2.5 to $3.0^{\circ} \mathrm{C}$ for $\mathrm{B} 2$ and generally it increases from the coastal areas to the central and northern continental interiors. High winter temperatures, yet in high altitudinal areas could result to changes in the hydrological balance due to reduced snowfall and snow cover and have serious impacts to winter tourism, thus also to the economy of the country. The different sea - land warming could be attributed to the differences in heat capacity and the fact that the evaporation of the sea water results to energy expenditure which due to the constant undulation and the vertical currents is transferred to lower depths. Thus, the surface temperature above the sea will not increase so much. Another factor resulting to this difference between the land and the sea future change could be the lower skill of the model in simulating the orography, the altitude and the vegetation of the costal Greek area. If the above factors are underestimated (lower altitude and vegetation) then the simulated temperature for the control period would be higher that the observational ones and the future temperatures will be more enhanced.

Furthermore the analysis of winter temperature projections showed that the models estimate a more intense warming of the Aegean Sea compared to the Ionian Sea. Using observational data and computing the equivalent composite maps for winter temperature for the period 1958-2000 (not shown) it was found that the mean winter temperature, for stations of the same latitude, is higher in the Ionian Sea. Therefore, the opposite warming that was found in the future projections could probably be a result of the land - sea interaction since in the Aegean Sea the influence of the intense warming of the extended continental area at the east (Turkey) is much more pronounced.

2. The warming is even higher during summer. The $A 2$ projections show an increase from 3.5 to $6^{\circ} \mathrm{C}$, the $\mathrm{A} 1 \mathrm{~B}$ from 3.5 to $5.5^{\circ} \mathrm{C}$ and the $\mathrm{B} 2$ from 3 up to $4.5^{\circ} \mathrm{C}$. As in winter, over land the temperature rise is more intense. The results are generally consistent with previous studies indicating that the Mediterranean region and southern Europe will exhibit an amplified temperature increase in comparison to the rest of the continent (Giorgi et al., 2004; Raisanen et al., 2004; Herting and Jacobeit 2008). This kind of intense warming especially when it is accompanied by low precipitation totals would have severe impacts in several aspects of human activities. Similar conditions during the extremely warm year of 2007 in Greece resulted in changes in the cultivation of several species and serious consequences in agriculture and 
national economy (Tolika et al., 2009). Also these climate conditions will play one of the most predominant roles to the increase in the number of forest fires.

3. Winters are estimated to be drier by the end of the $21^{\text {st }}$ century. The A2 and the A1B forcing scenarios estimate a decrease up to $-30 \%$ in southern Greece, while for the B2 scenario the precipitation reduction is almost half (up to $-15 \%$ ) and moreover some parts of northeastern Greece will have a small rainfall increase. According to Giorgi et al., 2004 the overall winter rainfall decrease over the Mediterranean could probably be attributed to the increase of the anticyclonic circulation over the region. The future change in the SLP values is not so intense increasing up to $1.5 \mathrm{hPa}$ for $\mathrm{A} 1 \mathrm{~B}$. However, it should be considered quite significant since the actual SLP future values are much higher than the observational ones in the control period. It is worth noting that the SLP ENSEMBLES projections are characterized as "too anticyclonic" compared to the observational SLP values especially over the Mediterranean region, indicating an increase in the frequency of anticyclonic activity over the area (van der Linden at al., 2009). For example HadAM3H which forced all PRUDENCE simulations exhibits a stronger pressure gradient across a large part of Central to Northern Europe than the ERA-40 reanalysis which is mainly caused by too high pressure over the Mediterranean region and too deep Icelandic low extending too far into the Nordic seas (Jacob et al., 2007). In fact, the projections of the PRUDENCE models showed a small decrease of the future SLP values but the mean pressure field reviled the strong anticyclonic circulation $(1022 \mathrm{hPa})$ over the domain of study. All the above lead to a lower frequency of occurrence of low pressure systems or more shallow cyclones over Greece.

4. The drier future summers is also one of the common features in all the models used in the study. The expected changes of summer precipitation due to the anthropogenic emission of greenhouse gases in Greece showed a prevailing decrease or rainfall heights up to $-60 \%$ with respect to the reference period. This maximum drying was assessed from the A2 PRUDENCE group of models and characterizes mainly the areas of Peloponnisos and eastern Aegean Sea. The other projections estimated a quite smaller decrease. Examining the future change of extreme precipitation indices, Maheras et al. (2008) also noted that Greece will experience a persisting absence of rainfall, since the projections of some of the ENSEMBLES models showed that the future length of the maximum dry spells would approach 90days. This summer drying is probably associated with the SLP increase over the British Isles as well as the weakening of the westerly flow which with a positive feedback with the soil-moisture depletion is expected to result to both dryer and warmer conditions over the domain of study (Zanis et al., 2009). Also, over eastern Mediterranean all the models predict a SLP decrease. This is probably a result of the intense temperature increase in the Middle East and an extension of the Pakistan Low (thermal low) to the west, over the domain of study. Finally the aforementioned land sea contrast in warming, according to Rowell and Jones (2006) results to the reduction of the relative humidity in air advected to the continent as so to the reduction of precipitation.

5. The different resolution between the PRUDENCE and the ENSEMBLES groups of models seem to give in some cases more detailed information about the future change in the two parameters under examination. This is more obvious in the continental parts of the country where the ENSEMBLES models seem to capture more efficient the sharp orography and the altitudinal differences of the country. Finally, as it was expected, the A2 scenario characterized as the most pessimistic one presented the most intense changes both for temperature and precipitation followed by $\mathrm{A} 1 \mathrm{~B}$ and then $\mathrm{B} 2$ scenario. However, the relatively more intense changes in the atmospheric circulation projected by $\mathrm{B} 2$ in comparison to $\mathrm{A} 1 \mathrm{~B}$ could probably be attributed to the different "parent" GCMs that were used in the ENSEMBLES A1B group in comparison to the PRUDENCE B2 group of models.

\section{ACKNOWLEDGEMENTS}

Data have been provided through the PRUDENCE data archive, funded by the EU through contract EVK2-CT2001-00132. This study has been supported by the European Commission ENSEMBLES project (Contract number GOCE-CT-2003-505539). The authors would also like to acknowledge that part of the work was carried out within the framework of the Operational Program "Competitiveness and Entrepreneurship" of the National Strategic Reference Framework (NSRF) - Research Funding Program COOPERATION 2009 (no 09COP-31-1094, Title "Development of a Geographic Climate Information System). 


\section{REFERENCES}

Anagnostopoulou C., Tolika K., Maheras P., Kutiel H. and Flocas H.A., (2008) Performance of the general circulation HadAM3P model in simulating circulation types over the Mediterranean region, International Journal of Climatology, 28, 185-203.

Barry R. and Carleton A. (2001) Synoptic and Dynamic Climatology, Routledge, London and New York, $620 \mathrm{pp}$.

Böhm U., Kucken M., Ahrens W., Block A., Hauffe D., Keuler K., Rckel B. and Will A., (2006) Clm- the climate version of Im: Brief description and long term applications, COSMO Newsletter, 6, 225-235.

Buonomo E., Jones R., Huntingford C., Hannaford J., (2007) On the robustness of changes in extreme precipitation over Europe from tow high resolution climate change simulations, Quarterly Journal of the Royal Meteorological Society, 133, 65-81.

Castro M., Fernan dez C., Gaertner M.A., (1993) Description of a mesoscale atmospheric numerical model, In: Mathematics, Climate and Environment, Diaz J.L., Lions J.L. (eds), Masson, Paris; 273 pp.

Christensen O.B., Christensen J.H., Machenhauer B., Botzet M., (1998) Very High-Resolution Regional climate simulations over Scandinavia - Present Climate, Journal of Climate, 11, 3204-3229.

Collins M., Booth B.B., Harris G.R., Murphy J.M., Sexton D., Webb M.J., (2006) Towards quantifying uncertainty in transient climate change, Climate Dynamics, 27, 127-147.

Döscher R., Willén U., Jones C., Rutgersson A., Meirer H.E.M., Hanson U., Graham L.P., (2002) The development of the coupled regional ocean-atmosphere model RCAO, Boreal Environment Research, 7, 183-192.

Giorgi F., (2006) Climate change hot-spots, Geophysical Research Letters, 33, L088707, DOI:10.1029/2006GL025734.

Giorgi F., Mearns L.O., (1999) Introduction to special section: regional climate modelling revisited, Journal of Geophysical Research, 104, 6335-6352.

Giorgi F., Lionello P., (2008) Climate change projections for the Mediterranean region, Global and Planetary Change, 63, 90-104.

Giorgi F., Bi X., Pal J., (2004) Mena, interannual variability and trends in a regional climate change experiment over Europe. II: climate change scenarios (2071-2050), Climate Dynamics, 23, 839-858.

Hatzianastassiou N., Katzoulis B., Pnevmatikos J., Antakis V., (2008) Spatial and temporal variation of precipitation in Greece and surrounding regions based on global precipitation climatology project data, Journal of Climate 21, 1349-1370.

Haugen J.E., Haakenstad H., (2006) Validation of HIRHAM version 2 with 50kim and 25km resolution, RegClim General Technical Report, No. 9, pp 159-173.

Hertig E., Jacobeit J., (2008) Downscaling future climate change: Temperature scenarios for the Mediterranean area, Global and Planetary Change, 63, 127-131.

Jacob D., (2001) A note of the simulation of the annual and inter-annual variability of the water budget over the Baltic Sea drainage basin, Meteorology and Atmospheric Physics, 77, 61-73.

Jacob D., Bärring L., Christensen O.B., Christensen J.H., de Castro M., Déqué M., Giorgi F., Hagemann S., Hirschi M., Jones R., Kjellström E., Lenderink G., Rockel B., Sánchez E., Schär C., Seneviratne S.I., Somot S., van Ulden A., van den Hurk B., (2007) An inter-comparison of regional climate models for Europe: model performance in present-day climate, Climatic Change, 81, 31-52.

Jones C.G., Willén U., Ullersting A., Hansson U., (2004) The Rssby Centre regional atmospheric climate model part I: model climatology and performance for the present climate over Europe, Ambio, 33, 199-210.

Kjellström E., Barring L., Gollvik S., Hansson U., Jones C., Samuelsson P., Rummukainen M., Ullerstig A., Willén U., Wyser K., (2005) A 140-year simulation of European climate with the new version of the Rossby Centre regional atmospheric climate model (RCA3), Reports Meteorology and Climatology, 108, SMHI, SE-60176 Norrkoping, Sweden, 55pp.

Krichak S.O., Alpert P., Bassat K., Kunin P., (2007) The surface climatology of the eastern Mediterranean region obtained in a three member ensemble climate change simulation experiment, Advances in Geosciences, 12, 67-80.

Kostopoulou E., Giannakopoulos C., Anagnostopoulou C., Tolika K., Maheras P., Vafiadis M., Founda D., (2007) Simulating maximum and minimum temperature over Greece: a comparison of three downscaling techniques, Theoretical and Applied Climatology, 90, 65-82.

Lenderink G., van den Hurk B., van Meijgaard E., van ulden A, Cuijpers H., (2003) Simulation of present - day climate in RACHMO2: first results and model developments. Technical Report TR-252. Royal Netherlands Meteorological Institute, De Bilt.

Lionello P., Platon S., Rodó X., (2008) Editorial Preface: Trends and climate change in the Mediterranean region, Global and Planetary Change, 63, 87-89. 
Lolis C.J., Bartzokas A., Metaxas D.A., (1999) Spatial covariability of the cliamtic parameters in the Greek area, International Journal of Climatology, 19, 185-196.

Lorenz D.J., DeWeaver E.T., (2007) Tropopause height and zonal wind response to global warming in the IPCC scenario integrations, Journal of Geophysical Research, 112, D10119. DOI:10.1029/2006JD008087.

Maheras P., Anagnostopoulou C., (2003) Circulation types and their influence on the interannual variability and precipitation changes in Greece. In: Bolle HJ (ed) Mediterranean climate: variability and trends, Berlin, Springer, pp 215-239.

Maheras P., Tolika K., Kostopoulou E., Anagnostopoulou C., Flocas H., Hatzaki M., Tegoulias I., Rousi E., (2008) ENSEMBLES Milestones 4.3.5: Mediterranean extremes in RCM scenario runs summarised, pp. 84

Meehl GA., Tebaldi C. (2004) More intense, more frequent, and longer lasting heat waves in the 21 st century, Science, 305, 994--997.

Nakicenovic N., Alcamo J. and co-authors. (2000) IPCC Special Report on Emissions Scenarios, Cambridge University Press, Cambridge.

Raisanen J., Hansson U., Ullerstig A., Doscher R., Graham L.P., Jones C., Meier H.E.M., Samuelsson P., Willen U., (2004) European Climate in the late twenty - first century: regional simulations with two driving global models and two forcing scenarios, Climate Dynamics, 22, 12-31.

Rauscher S.A., Coppola E., Piani C., Giorgi F., 2010. Resolution effects on regional climate model simulations of seasonal precipitation over Europe, Clim. Dyn., 35(4), 685-711.

Rowell D.P., Jones R.G., (2006) Causes and uncertainty of future summer drying over Europe, Climate Dynamics, 27, 281-299.

Sanchez-Gomez, E., Somot, S., Déqué, M., 2009. Ability of an ensemble of regional climate models to reproduce weather regimes over Europe-Atlantic during the period 1961-2000, Clim Dyn., 33,723736.

Schär C., Vidale P.L., Lüthi D., Frei C., Häberli C., Liniger M.A., Appenzeller C., (2004) The role of increasing temperature variability in European summer heatwaves, Nature, 427, 332--336. DOI:10.1038 /nature02300.

Somot S., Sevault F., Déqué M., (2006) Transient climate change scenario simulation of the Mediterraean Sea for the twenty-first century using a high-resolution ocean circulation model, Climate Dynamics, 27, 851-879.

Somot S., Sevault F., Déqué M., Crépon M., (2008) 21st century climate change scenario for the Mediterranean using a coupled atmosphere-ocean regional climate model, Global and Planetary Change, 63, 112-126.

Steppeler J., Doms G., Schattler U., Bitzer H.W., Gassmann A., Damrath U., Geregoric G., (2003) Mesogamma scale forecasts using the nonhydrostatic model LM, Meteorology and atmospheric Physics, 82, 75-96.

Tolika K., Maheras P., Vafiadis M., Flocas H.A., Arseni-Papadimitriou A., (2006) An evaluation of a General Circulation model (GCM) and the NCEP-NCAR Reanalysis data for winter precipitation in Greece, International Journal of Climatology, 26, 935-955.

Tolika K., Maheras P., Vafiadis M., Flocas H.A., Arseni-Papadimitriou A., (2007) Simulation of seasonal precipitation and raindays over Greece: a statistical downscaling technique based on artificial neural networks (ANNs), International Journal of Climatology, 27, 861-881.

Tolika K., Anagnostopoulou C., Maheras P., Vafiadis M., (2008) Simulation of future changes in extreme rainfall and temperature conditions over the Greek area: a comparison of two statistical downscaling approaches, Global and Planetary Change, 63, 132-151.

Tolika K., Maheras P., Tegoulias I., 2009. Extreme temperatures in Greece during (2007) Could this be a "return to the future"?, Geophysical Research Letters, 36, L10813, DOI: 10.1029/2009GL038538.

van der Linden and co-authors (2009) ENSEMBLES: Climate change and its impacts at seasonal, decadal and centennial timescales. Summary of research and results fromt eh ENSEMBLES project. pp. 160

van Ulden A., Lenderink G., van den Hurk B., van Meijgaard E., (2007) Circulation statistics and climate change in Central Europe: PRUDENCE simulations and observations, Climatic Change, 81, 179-192.

Vidale P.L., Luthi D., Frei C., Seneviratne S.I., Schar C., (2003) Predictability and uncertainty in a regional climate model, Journal of Geophysical Resarch, 108(D18), 4586, DOI: 10.1029/2002JD002810.

Xoplaki E., (2002) Climate variability over the Mediterranean, PhD thesis, University of Bern, Switzerland, pp. 190.

Zanis P., Kapsomenakis I., Philandras C., Douvis K., Nikolakis D., Kanellopoulou E., Zerefos C., Repapis C., (2009) Analysis of an ensemble of present day and future regional climate simulations for Greece, International Journal of Climatology, 29, 1614-1633. 